\title{
A METHOD OF AIRCRAFT RELIABILITY ASSESSMENT AS REFERRED TO THE OPERATIONAL-USE SAFETY
}

\section{METODA OCENY NIEZAWODNOŚCI STATKÓW POWIETRZNYCH NA PODSTAWIE INFORMACJI O ICH USZKODZENIACH W SYSTEMIE EKSPLOATACJI}

\author{
Antonina Krutkow ${ }^{1}$, Mieczysław Pigłas ${ }^{2}$, Mariusz Zieja ${ }^{3}$ \\ $(1,2,3)$ Air Force Institute of Technology \\ ul. Księcia Bolesława 6, 01-494 Warszawa, Poland \\ E-mails: (1) antonina.krutkow@itwl.pl, (2) mieczyslaw.piglas@itwl.pl,
}

(3) mariusz.zieja@itwl.pl

\begin{abstract}
Throughout the operational phase of aviation objects, the safety and reliability thereof are characterised with a set of a dozen or so, or even tens of indices correlated with each other. Hence, any analytical and assessment-oriented efforts as well as comparisons - for any specific feature - between both the objects themselves and the systems of manufacturing, operating, and maintaining them are usually hindered. The intended aim of this paper is to suggest some solution to this problem, one that consists in reducing the number of operational indices of safety down to several indices of significance which contain most information on the object under assessment or on a system of operating this object
\end{abstract}

Key words: reliability, safety, operational use, aircraft

Streszczenie. Proces realizacji obiektów lotniczych charakteryzowany może być zbiorem kilkunastu lub nawet kilkudziesięciu, skorelowanych między soba, wskaźników oceny. Utrudnia to prowadzenie analiz oraz porównywanie między soba pod względem określonej cechy zarówno samych obiektów, jak i systemu ich realizacji. W niniejszej pracy zaproponowano sposób rozwiazania tego problemu, polegajacy na zawężeniu liczby wskaźników do kilku istotnych, zawierajacych najwięcej informacji o ocenianym elemencie oraz zbudowanie na ich podstawie nowych wskaźników, niezależnych między soba w sensie statystycznym.

Słowa kluczowe: niezawodność, bezpieczeństwo, eksploatacja, statek powietrzny 


\section{Introduction}

Capability of making comparisons between failure frequencies, prerequisites for (air) accidents, and other properties decisive to the operational-use safety (as referred to individual components of a system of operating aviation-dedicated objects) is of significance while assessing the process of operating and maintaining such objects. The following sets can be understood as such components:

- sets of various types of aircraft (SP) or of some structural components thereof, of major importance to the whole aircraft, e.g. power plants $(\mathrm{ZN})$ operated by/within a given air system,

- sets of aviation organisations which operate a given type of aircraft (SP),

- aircraft (SP) or power plants (ZN) made by one manufacturer, etc.

Let us assume that some specific component of the system of operating any aviation-dedicated object is featured with a set of indices $\Omega$ :

$$
\begin{array}{ll} 
& \mathbf{\Omega}=\left\{\mathrm{X}_{1}, \mathrm{X}_{2}, \ldots, \mathrm{X}_{\mathrm{k}}\right\} \\
\mathrm{X}_{1}=\left\{\mathrm{X}_{11}, \mathrm{X}_{12}, \ldots, \mathrm{X}_{1 \mathrm{j}}\right\} & \\
\mathrm{X}_{2}=\left\{\mathrm{X}_{21}, \mathrm{X}_{22}, \ldots, \mathrm{X}_{2 \mathrm{j}}\right\} \\
\ldots \ldots \ldots \ldots \ldots \ldots \ldots \ldots \ldots \ldots \ldots \ldots \\
\mathbf{\Omega} \subset \mathbf{Z}, \quad \mathbf{Z}=\left\{\mathrm{X}_{\mathrm{k} 1}, \mathrm{X}_{\mathrm{k} 2}, \ldots, \mathrm{X}_{\mathrm{kj}}\right\} \quad \mathrm{Z}=\left\{\mathrm{X}_{1}, \mathrm{X}_{2}, \ldots, \mathrm{X}_{\mathrm{r}}\right\} \quad \mathrm{k} \leq \mathrm{r},
\end{array}
$$

where:

$\mathrm{r}$ - number of indices accepted for evaluation of the system of operating an aviation-dedicated object,

$\mathrm{k}$ - number of indices accepted for evaluation of any selected component of the system of operating an aviation-dedicated object,

$\mathrm{j}$ - number of evaluated characteristics of any selected component of the system of operating an aviation-dedicated object.

In practice, the $\boldsymbol{\Omega}$ set can comprise a dozen or so, or several dozen indices. Taking this into account, as well as the assumptions that:

- the $X_{1}, \ldots, X_{k}$ indices accepted to characterise a given component of the system of operating an aviation-dedicated object, are correlated, and

- any of these indices characterises only some selected property of a given component of the system of operating an aviation-dedicated object,

the following is to be stated: making any statements and/or comparisons of constituents of a given component of the system of operating an aviation-dedicated object, according to any index, is rendered difficult and in practice unfeasible if the number of statements is higher than 2 (two).

Any problem can, therefore, be solved by means of the solution proposed in (Pigłas, 1990), i.e.: 
- the number of indices should become limited to several of the greatest importance from the standpoint of evaluation of any selected component of the system of operating an aviation-dedicated object,

- on the grounds of these indices some independent ones should be determined.

New indices determined in such a way require some relevant physical interpretation.

\section{Selection of indices of significance}

To restrict the $\Omega$ set of indices to evaluate any component of the system of operating an aviation-dedicated object to indices of significance only, one should:

- select only one index from the $\boldsymbol{\Omega}$ set, such as to best describe the component under evaluation with reference to safety, i.e. the so-called 'explained index',

- select from the $\Omega$ set such a subset of indices, the so-called 'explanatory indices', which significantly affect the level of the 'explained index'.

The 'explanatory indices' are those satisfying the following conditions (Pluta, 1972):

1) are strongly correlated with the 'explained index',

2) lack correlation, or are only slightly correlated, with each other.

Therefore, from among the indices in the $\boldsymbol{\Omega}$ set which meet condition no. 1, i.e. when the following relationship takes place:

$$
\mathrm{a}_{1 \mathrm{~s}}<\mathrm{a}_{\mathrm{kr}}
$$

those are selected, for which meeting the condition no. 2 is true, i.e. when the following inequality proves correct (Barziłowicz, et al.,1982).:

$$
\mathrm{a}_{\mathrm{rs}}>\mathrm{a}_{\mathrm{kr}}
$$

where:

a - elements of matrix $\mathbf{A}$, representing distances between the indices in the $\boldsymbol{\Omega}$ set: 


$$
\mathbf{A}=\left[\begin{array}{ccccccc}
0 & \mathrm{a}_{12} & \ldots & \mathrm{a}_{1 \mathrm{~s}} & \ldots & \mathrm{a}_{1, \mathrm{k}-1} & \mathrm{a}_{1 \mathrm{k}} \\
\mathrm{a}_{21} & 0 & \ldots & \mathrm{a}_{2 \mathrm{~s}} & \ldots & \mathrm{a}_{2, \mathrm{k}-1} & \mathrm{a}_{2 \mathrm{k}} \\
\ldots & \ldots & \ldots & \ldots & \ldots & \ldots & \ldots \\
0 & 0 & \ldots & \mathrm{a}_{\mathrm{rs}} & \ldots & \mathrm{a}_{\mathrm{r}, \mathrm{k}-1} & \mathrm{a}_{\mathrm{rk}} \\
\ldots & \ldots & \ldots & \ldots & \ldots & \ldots & \ldots \\
\mathrm{a}_{\mathrm{k}-1,1} & \mathrm{a}_{\mathrm{k}-1,2} & \ldots & \ldots & \ldots & 0 & \mathrm{a}_{\mathrm{k}-1, \mathrm{k}} \\
\mathrm{a}_{\mathrm{k} 1} & \mathrm{a}_{\mathrm{k} 2} & \ldots & \ldots & \ldots & \mathrm{a}_{\mathrm{k}, \mathrm{k}-1} & 0
\end{array}\right]_{\mathrm{k} * \mathrm{k}}
$$

$a_{r s}$ - distance between the $X_{r}$ and the $X_{s}$ in the $\Omega$ set:

$$
a_{r s}=a_{s r}=\frac{1}{j} \sum_{i=1}^{j}\left|\bar{x}_{r i}-\bar{x}_{s i}\right|
$$

$a_{1 s}$ - distance between the explained index $X_{1}$ and the explanatory index $X_{s}$ in the $\boldsymbol{\Omega}$ set:

$$
a_{1 s}=a_{s 1}=\frac{1}{j} \sum_{i=1}^{j}\left|\bar{x}_{1 i}-\bar{x}_{s i}\right|
$$

$\bar{x}_{r i}$ - standardised values of the $r$-th index for the $i$-th element of the examined statistical population:

$$
\bar{x}_{r i}=\frac{x_{r i}-E\left(X_{r}\right)}{\sqrt{D^{2}\left(X_{r}\right)}}
$$

$\mathrm{E}\left(\mathrm{X}_{\mathrm{r}}\right)$ - the expected value of the $\mathrm{r}$-th index in the $\boldsymbol{\Omega}$ set:

$$
E\left(X_{r}\right)=\frac{1}{j-1} \sum_{i=1}^{j} x_{r i}
$$

$\mathrm{D}^{2}\left(\mathrm{X}_{\mathrm{r}}\right)$ - variance of the $\mathrm{r}$-th index in the $\boldsymbol{\Omega}$ set:

$$
D^{2}\left(X_{r}\right)=\frac{1}{j-1} \sum_{i=1}^{j}\left[x_{r i}-E\left(X_{r}\right)\right]^{2}
$$


$\overline{\mathrm{x}}_{\mathrm{si}}$ - standardised values of the s-th index for the i-th element of the examined statistical population:

$$
\bar{x}_{s i}=\frac{x_{s i}-E\left(X_{s}\right)}{\sqrt{D^{2}\left(X_{s}\right)}}
$$

$\mathrm{a}_{\mathrm{kr}}$ - a critical value of distance between the A matrix elements.

The critical value $\mathrm{a}_{\mathrm{kr}}$ can be found from the following formula:

$$
\mathrm{a}_{\mathrm{kr}}=\overline{\mathrm{a}}-\varphi \cdot \mathrm{S}_{\mathrm{a}}
$$

where: $\overline{\mathrm{a}}=\frac{1}{\mathrm{n}} \sum_{\mathrm{i}=1}^{\mathrm{n}} \mathrm{a}_{\mathrm{i}}$

$$
\begin{aligned}
& \mathrm{S}_{\mathrm{a}}=\frac{1}{\mathrm{n}-1} \sum_{\mathrm{i}=1}^{\mathrm{n}}\left(\mathrm{a}_{\mathrm{i}}-\overline{\mathrm{a}}\right)^{2} \\
& \mathrm{n}=\mathrm{k}(\mathrm{k}-1) \\
& \left.\mathrm{a}_{\mathrm{i}} \text { - the i-th element of the A matrix (without elements } \mathrm{a}_{11}, \mathrm{a}_{22}, \ldots, \mathrm{a}_{\mathrm{kk}}\right), \\
& \varphi-\text { index that takes values } 0 \text { through } 2 .
\end{aligned}
$$

\section{Determination of the independent indices}

Found in the above-presented way, the explained index and the explanatory indices are the richest sources of information on a given component of the system of operating an aviation-dedicated object. They build up a set of indices $\mathbf{X}$

$$
\mathbf{X}=\left(\mathrm{X}_{1}, \ldots, \mathrm{X}_{\mathrm{p}}, \ldots, \mathrm{X}_{\mathrm{n}}\right), \mathrm{n} \leq \mathrm{k} \quad \mathrm{X} \subset \boldsymbol{\Omega}
$$

to evaluate this element of the following variance:

$$
D^{2}\left(X_{p}\right)=\frac{1}{j-1} \sum_{i=1}^{j}\left[x_{p i}-E\left(X_{p}\right)\right]^{2}
$$

On the grounds of these indices it is possible to build up another, new indices of evaluation.

As an instance, if one of the indices included in the $\mathbf{X}$ set - e.g. the explained index $\mathrm{X}_{1}$ given designation $\mathrm{V}_{1}$, i.e. 


$$
\mathrm{V}_{1}=\mathrm{X}_{1} \text {, }
$$

is accepted as a new index, then the second one is determined in such a way as to make it lack correlation with $\mathrm{V}_{1}$, for example:

$$
\mathrm{V}_{2}=\gamma_{21} \mathrm{~V}_{1}+\mathrm{X}_{2} \text {, }
$$

the third one is determined in such a way as to make it lack correlation with $\mathrm{V}_{1}$ and $\mathrm{V}_{2}$, for example:

$$
\mathrm{V}_{3}=\gamma_{31} \mathrm{~V}_{1}+\gamma_{32} \mathrm{~V}_{2}+\mathrm{X}_{3} \text { etc., }
$$

where: $\gamma_{21}, \gamma_{31}, \gamma_{32} \ldots$ - constant coefficients determined from the condition of lack of correlation with the indices $V_{2}$ and $V_{1}, V_{3}$ and $V_{1}, V_{3}$ and $V_{2}, \ldots$, then originated is the $n$ system of indices $V_{p}$ being the sum of the index $X_{p}$ and the linear combination of indices $V_{1}, \ldots, V_{p-1}$ with the coefficients $\gamma_{p m}$, for $p=1, \ldots, n$, $\mathrm{m}=1, \ldots, \mathrm{n}-1$ :

$$
\begin{gathered}
\mathrm{V}_{1}=\mathrm{X}_{1} \\
\mathrm{~V}_{\mathrm{p}}=\sum_{\mathrm{m}=1}^{\mathrm{p}-1} \gamma_{\mathrm{pm}} \mathrm{V}_{\mathrm{m}}+\mathrm{X}_{\mathrm{p}}, \quad \mathrm{p}=2,3, \ldots, \mathrm{n}
\end{gathered}
$$

The matrix of coefficients takes the form:

$$
\gamma=\left[\begin{array}{cccccccccc}
1 & 0 & 0 & \ldots & 0 & \ldots & 0 & 0 & \ldots & 0 \\
\gamma_{21} & 1 & 0 & \ldots & 0 & \ldots & 0 & 0 & \ldots & 0 \\
\ldots & \ldots & \ldots & \ldots & \ldots & \ldots & \ldots & \ldots & \ldots & \ldots \\
\gamma_{\mathrm{p} 1} & \gamma_{\mathrm{p} 2} & \gamma_{\mathrm{p} 3} & \ldots & \gamma_{\mathrm{pm}} & \ldots & \gamma_{\mathrm{p}, \mathrm{p}-1} & 1 & \ldots & 0 \\
\cdots & \ldots & \ldots & \ldots & \ldots & \ldots & \ldots & \ldots & \ldots & \ldots \\
\gamma_{\mathrm{n} 1} & \gamma_{\mathrm{n} 2} & \gamma_{\mathrm{n} 3} & \ldots & \gamma_{\mathrm{nm}} & \ldots & \ldots & \ldots & \gamma_{\mathrm{n}, \mathrm{n}-1} & 1
\end{array}\right]_{\mathrm{n} * \mathrm{n}}
$$

The $\gamma_{\mathrm{pm}}$ coefficients can be found in the effect of solving the system of equations (6), in succession, against $X_{1}, X_{2}, \ldots, X_{n}$ : 


$$
\begin{aligned}
& \mathrm{X}_{1}=\mathrm{V}_{1} \\
& \mathrm{X}_{2}=-\gamma_{21} \mathrm{~V}_{1}+\mathrm{V}_{2} \\
& \mathrm{X}_{\mathrm{p}}=-\gamma_{\mathrm{p} 1} \mathrm{~V}_{1}-\gamma_{\mathrm{p} 2} \mathrm{~V}_{2}+\ldots-\gamma_{\mathrm{pm}} \mathrm{V}_{\mathrm{m}}+\ldots-\gamma_{\mathrm{p}, \mathrm{p}-1} \mathrm{~V}_{\mathrm{p}-1}+\mathrm{V}_{\mathrm{p}} \\
& \mathrm{X}_{\mathrm{n}}=-\gamma_{\mathrm{n} 1} \mathrm{~V}_{1}-\gamma_{\mathrm{n} 2} \mathrm{~V}_{2}+\ldots-\gamma_{\mathrm{nm}} \mathrm{V}_{\mathrm{m}}+\ldots-\gamma_{\mathrm{n}, \mathrm{n}-1} \mathrm{~V}_{\mathrm{n}-1}+\mathrm{V}_{\mathrm{n}}
\end{aligned}
$$

For any indices $X_{m}, X_{p}$ being a linear function of the indices $V_{1}, \ldots, V_{m}, \ldots, V_{p}$

$$
\begin{gathered}
\mathrm{X}_{\mathrm{m}}=\sum_{\mathrm{i}=1}^{\mathrm{m}} \mathrm{a}_{\mathrm{i}} \mathrm{V}_{\mathrm{i}}+\mathrm{b} \\
\mathrm{X}_{\mathrm{p}}=\sum_{\mathrm{i}=1}^{\mathrm{p}} \mathrm{c}_{\mathrm{i}} \mathrm{V}_{\mathrm{i}}+\mathrm{d}, \quad \mathrm{m} \leq \mathrm{p}
\end{gathered}
$$

variance and covariance are determined with the following formulae:

$$
\begin{aligned}
& D^{2}\left(X_{m}\right)=\sum_{i, j=1}^{m} a_{i} a_{j} \operatorname{cov}\left(V_{i}, V_{j}\right) \\
& \operatorname{cov}\left(X_{p}, X_{m}\right)=\sum_{i, j=1}^{m} a_{i} c_{j} \operatorname{cov}\left(V_{i}, V_{j}\right)
\end{aligned}
$$

When there is no correlation between the indices $V_{i}, V_{j}$

$$
\operatorname{cov}\left(V_{i}, V_{j}\right)=0 \quad \text { for } \quad i \neq j, \quad i, j=1,2, \ldots, n
$$

and expressions (9) and (10) take the following forms:

$$
\begin{gathered}
\mathrm{D}^{2}\left(\mathrm{X}_{\mathrm{m}}\right)=\sum_{\mathrm{i}=1}^{\mathrm{m}}\left(\mathrm{a}_{\mathrm{i}}\right)^{2} \mathrm{D}^{2}\left(\mathrm{~V}_{\mathrm{i}}\right), \\
\operatorname{cov}\left(\mathrm{X}_{\mathrm{p}}, \mathrm{X}_{\mathrm{m}}\right)=\sum_{\mathrm{i}=1}^{\mathrm{m}} \mathrm{a}_{\mathrm{i}} \mathrm{c}_{\mathrm{i}} \mathrm{D}^{2}\left(\mathrm{~V}_{\mathrm{i}}\right)
\end{gathered}
$$

What is arrived at due to account taken of eq (8) in eqs (11) and (12) is:

$\mathrm{D}^{2}\left(\mathrm{X}_{1}\right)=\mathrm{D}^{2}\left(\mathrm{~V}_{1}\right)$ 


$$
\begin{aligned}
& D^{2}\left(X_{m}\right)=\sum_{\mu=1}^{m-1}\left(\gamma_{m \mu}\right)^{2} D^{2}\left(V_{\mu}\right)+D^{2}\left(V_{m}\right), \quad \text { for } m=2,3, \ldots, n \\
& \operatorname{cov}\left(X_{p}, X_{1}\right)=-\gamma_{p 1} D^{2}\left(V_{1}\right), \quad \text { for } p=2,3, \ldots, n, \\
& \operatorname{cov}\left(X_{p}, X_{m}\right)=\gamma_{p 1} \gamma_{m 1} D^{2}\left(V_{1}\right)+\ldots+\gamma_{p, m-1} \gamma_{m, m-1} D^{2}\left(V_{m-1}\right)-\gamma_{p m} D^{2}\left(V_{m}\right) \\
& \text { for } m=2,3, \ldots, p-1 ; \quad p=3,4, \ldots, n
\end{aligned}
$$

Hence, the unknown terms of the matrix $\gamma$ can be calculated from the following recurrence formulae:

$$
\begin{gathered}
\mathrm{D}^{2}\left(\mathrm{~V}_{1}\right)=\mathrm{D}^{2}\left(\mathrm{X}_{1}\right), \\
\gamma_{\mathrm{p} 1}=-\frac{\operatorname{cov}\left(\mathrm{X}_{\mathrm{p}}, \mathrm{X}_{1}\right)}{\mathrm{D}^{2}\left(\mathrm{~V}_{1}\right)}, \quad \text { for } \mathrm{p}=2,3, \ldots, \mathrm{n} \\
\mathrm{D}^{2}\left(\mathrm{~V}_{\mathrm{m}}\right)=\mathrm{D}^{2}\left(\mathrm{X}_{\mathrm{m}}\right)-\sum_{\mu=1}^{\mathrm{m}-1}\left(\gamma_{\mathrm{m} \mu}\right)^{2} \mathrm{D}^{2}\left(\mathrm{~V}_{\mu}\right), \\
\gamma_{\mathrm{pm}}=\frac{1}{\mathrm{D}^{2}\left(\mathrm{~V}_{\mathrm{m}}\right)}\left[\sum_{\mathrm{r}=1}^{\mathrm{m}-1} \gamma_{\mathrm{pr}} \gamma_{\mathrm{mr}} \mathrm{D}^{2}\left(\mathrm{~V}_{\mathrm{r}}\right)-\operatorname{cov}\left(\mathrm{X}_{\mathrm{p}}, \mathrm{X}_{\mathrm{m}}\right)\right], \\
\text { for } \mathrm{m}=2,3, \ldots, \mathrm{p}-1 ; \quad \mathrm{p}=3,4, \ldots, \mathrm{n} .
\end{gathered}
$$

It can be assumed that the distribution of the indices $X_{1}, \ldots, X_{n}$ of the $\mathbf{X}$ set is normal. Since the above found indices $V_{1}, \ldots, V_{n}$ are linear functions of the indices $X_{1}, \ldots, X_{n}$, then all distributions of the indices $V_{1}, \ldots, V_{n}$ and the conditional distributions thereof are also normal. Lack of correlation between the indices of normal distributions is equivalent to the independence of these indices (Pugaczew, 1968). Assuming the $\mathrm{V}_{1}, \ldots, \mathrm{V}_{\mathrm{n}}$ distribution to be normal, it can be inferred with probability $\alpha$ (assuming that usually $\alpha=0.9$ ) that there is a difference between $V_{p i}, i=1,2, \ldots, j$ and the expected value $E\left(V_{p}\right)$ :

$$
\left|\mathrm{V}_{\mathrm{pi}}-\mathrm{E}\left(\mathrm{V}_{\mathrm{p}}\right)\right|>1.25 \sqrt{\mathrm{D}^{2}\left(\mathrm{~V}_{\mathrm{p}}\right)}
$$

where: $1.25 \approx \mathrm{U}_{0.9}$ - quantile of the normal distribution, one that corresponds with $\alpha=0.9$.

It is convenient to use the non-dimensional form of the above written expression in the course of analysis (Barziłowicz, et al.,1982).:

$$
\bar{V}_{p i}= \pm \frac{V_{p i}-E\left(V_{p}\right)}{5 \sqrt{D^{2}\left(V_{p}\right)}}+0.5
$$


The $\bar{V}_{\mathrm{pi}}$ index takes value equal to 0.5 in the case the value of the $\mathrm{V}_{\mathrm{pi}}$ index is consistent with the expected value $\mathrm{E}\left(\mathrm{V}_{\mathrm{p}}\right)$, whereas in the case this value differs from the expected value by $2.5 \sqrt{\mathrm{D}^{2}\left(\mathrm{~V}_{\mathrm{p}}\right)}$, it takes values 0 or 1 .

The $(+)$ sign refers to the indices for which an increasing value proves improvement in features that describe a given component of the system of operating an aviation-dedicated object, the (-) sign - otherwise. Since probability of the event that

$$
\left|\mathrm{V}_{\mathrm{pi}}-\mathrm{E}\left(\mathrm{V}_{\mathrm{p}}\right)\right|>2.5 \sqrt{\mathrm{D}^{2}\left(\mathrm{~V}_{\mathrm{p}}\right)}
$$

is only slight and amounts to 0.013 , it can be assumed with great probability ( $\alpha=$ 0.987) that the $\bar{V}_{\mathrm{pi}}$ index takes any value from 0 through 1 . In the case of better components values of the $\bar{V}_{\mathrm{pi}}$ index will approach unity, whereas for the worse ones - zero. Components, for which $0.25 \leq \bar{V}_{\mathrm{pi}} \leq 0.75$, should be treated as those not straying from the average from the standpoint of the feature characterised by the $V_{p}$ index.

\section{Example and conclusions}

The way of determining independent indices and that of approaching the problem of physical interpretation thereof has been discussed using one of the components of the system of operating aviation-dedicated objects, i.e. a set of engines of an aircraft power plant. The intended aim of analysing this set is the assessment of reliability of different types of aero-engines. It has been assumed to assess this reliability in the course of operating/maintaining the engines with the $\boldsymbol{\Omega}$ set of 18 indices.

The experts method was used to determine the index $\mathrm{X}_{1}$, i.e. one which characterises best the reliability of aero-engines. This index is a number of flightsafety-affecting failures/damages to an engine per 1 (one) hour of its operation. It has been, therefore, selected as an explained index. Explanatory indices as referred to the $X_{1}$ index have been determined from eqs (2) and (3) on the grounds of information on failures/damages to 13 types of aero-engines, which occurred over 6-year operational use. These are the following indices:

$\mathrm{X}_{2}$ - a number of failures/damages to an engine per 1 (one) hour of its operation, detected within the maintenance system,

$\mathrm{X}_{3}$ - a number of failures/damages to an engine per 1 (one) hour of its operation, detected within the system of routine maintenance.

Together with the $X_{1}$ index they build up a set of indices of significance 


$$
\mathbf{X}^{\mathrm{SL}}=\left\{\mathrm{X}_{1}, \mathrm{X}_{2}, \mathrm{X}_{3}\right\}
$$

accepted for the needs of the aero-engines' reliability assessment.

For the indices from the $\mathbf{X}^{\mathrm{SL}}$ set, coefficients $\gamma_{\mathrm{pm}}$ were calculated with the eq (14) as the basis. These coefficients enable the independent indices $V_{1}, V_{2}, V_{3}$ to be determined from eq (6):

$$
\begin{gathered}
\mathrm{V}_{1}=\mathrm{X}_{1}, \\
\mathrm{~V}_{2}=\gamma_{21} \mathrm{~V}_{1}+\mathrm{X}_{2}, \\
\mathrm{~V}_{3}=\gamma_{31} \mathrm{~V}_{1}+\gamma_{32} \mathrm{~V}_{2}+\mathrm{X}_{3}
\end{gathered}
$$

To give physical interpretation of the newly determined rates $V_{p}$, its is convenient to represent them in the form of dependences on the rates $\mathrm{X}_{1}, \mathrm{X}_{2}, \mathrm{X}_{3}$ :

$$
\begin{gathered}
\mathrm{V}_{1}=\mathrm{X}_{1}, \\
\mathrm{~V}_{2}=\alpha_{21} \mathrm{X}_{1}+\mathrm{X}_{2}, \\
\mathrm{~V}_{3}=\alpha_{31} \mathrm{X}_{1}+\alpha_{32} \mathrm{X}_{2}+\mathrm{X}_{3}
\end{gathered}
$$

The courses of changes in values of coefficients in individual years are presented in Fig. 1.

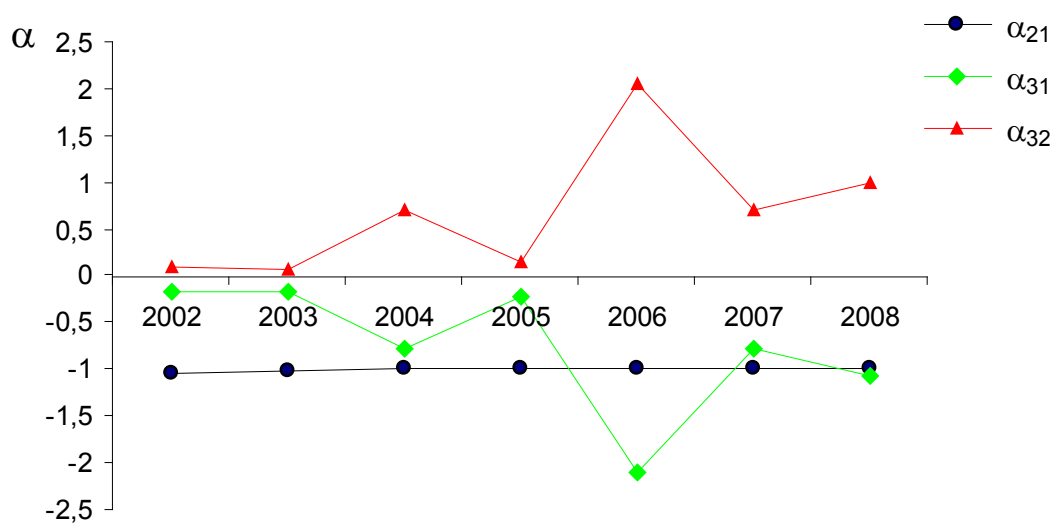

Fig. 1 Changes in values of the $\alpha_{p m}$ coefficients in the years 2002-2008

What follows from Fig. 1. is that the $\alpha_{\mathrm{pm}}$ coefficients are featured in subsequent years with sign stability. They also show high stability of values. 
The first index $\mathrm{V}_{1}$ describes the number of failures/damages to an engine per 1 (one) hour of its operation, which occurred within the system of operating it. Therefore, it has been assumed that this index is characterised with such a reliability feature as the engine's vulnerability within the system of operating it.

The second index $V_{2}$ is independent of the $V_{1}$ index. Its value grows greater as the lower is value of the $X_{1}$ index (i.e. as the total number of failures decreases) and the higher is value of the $\mathrm{X}_{2}$ index (i.e. the greater number of failures/damages is detected within the maintenance system). It can be, therefore, assumed that this index characterises susceptibility of the structure to detection of failures/damages within the maintenance system. The greater value of the $V_{2}$ index characterising a given engine type, the higher is the assessment of the engine, as referred to the feature characterised by this index.

The third index $V_{3}$ is independent of the indices $V_{1}$ and $V_{2}$. Its value is higher as the value of the $X_{1}$ index is lower and those of the $X_{2}$ and $X_{3}$ indices are higher. The greater value of the $V_{3}$ index characterising a given engine structure, the higher is the assessment of the engine, as referred to the feature characterised by this index, since it means that the structure is featured with:

- low number of failures/damages,

- failures/damages are detected first and foremost within the maintenance system,

- within the maintenance system, the failures/damages are detected first of all in the course of routine maintenance (i.e. there is high susceptibility of the structure to early detection of failures/damages).

Therefore, it can be assumed that the $\mathrm{V}_{3}$ index describes such a feature of an engine as the amount and level of labour put into the engine's structure.

By way of example, Fig. 2 shows distributions of independent indices $V_{1}, V_{2}, V_{3}$ which characterise reliability of aero-engines. The indices have been derived from the operational indices $\mathrm{X}_{1}, \mathrm{X}_{2}, \mathrm{X}_{3}$ calculated on the grounds of information on failures/damages to engines in the years 2000 to 2006.

Different engine types have been designated with the following numbers:

$02,04,06,11,12,21,22,31$ - turbojet engines,

72 - turbofan,

41, 42, 43 - helicopter turbine engines,

81 - piston engine.

The (-) and (+) signs have been used to designate those types of engines that stray in negative or positive sense, respectively - from the average level of the feature characterised by the index $V_{p}$.

What follows from Fig. 2 is the conclusion that engines 21 and 22 are featured with the highest level of vulnerability. Despite of this fact, the structures of these engines deserve favourable assessment from the viewpoint of their susceptibility to detection of failures/damages within the maintenance system . For the same reason, engines designated with numbers $04,31,41,42,72$ deserve the same assessment. 
As far as the amount and level of labour put into the engine's structure are concerned, engines designated with numbers 06 and 11 should be ranked highest. They show high level of failures/damages detectability within the system of routine maintenance. Analysis of changes in values of independent indices throughout longer periods of operating the engines proves to be a factor of significance from the point of view of correct inference.
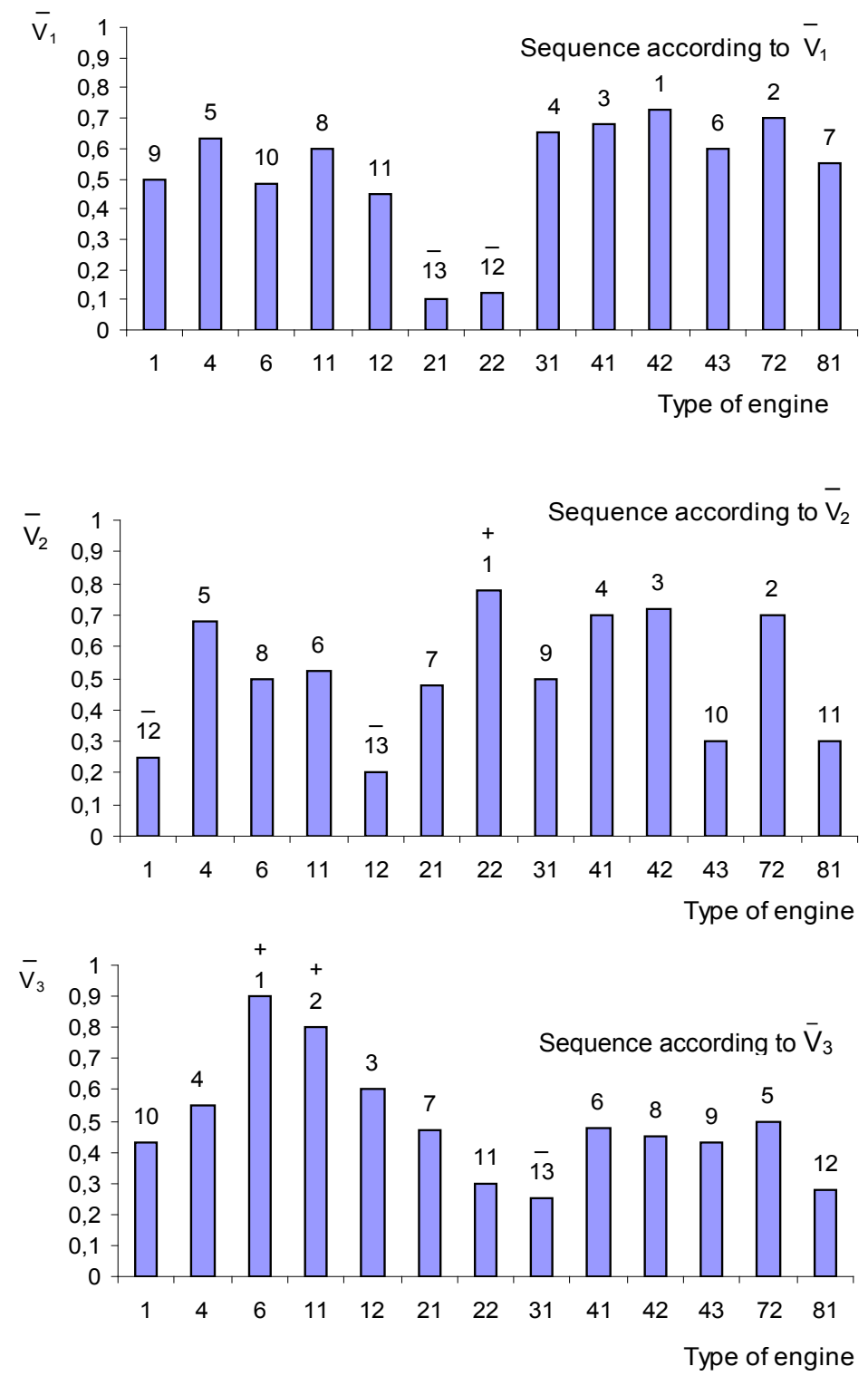

Fig. 2. Distribution of values of the independent rates $\mathrm{V}_{\mathrm{p}}$ which characterise aero-engines reliability 
As an instance, Fig. 3 shows the course of changes in value of the $V_{p}$ index for the engine designated with '02', based on information on failures/damages which occurred to this engine in the years 2002-2008. The engine was featured throughout this time with: (a) constant average level of susceptibility to failures/damages, (b) constant and relatively low (as compared to other engines) level of failures/damages detected within the maintenance system, (c) continuously decreasing (as compared to other engines) amount and level of labour put into the engine's structure.

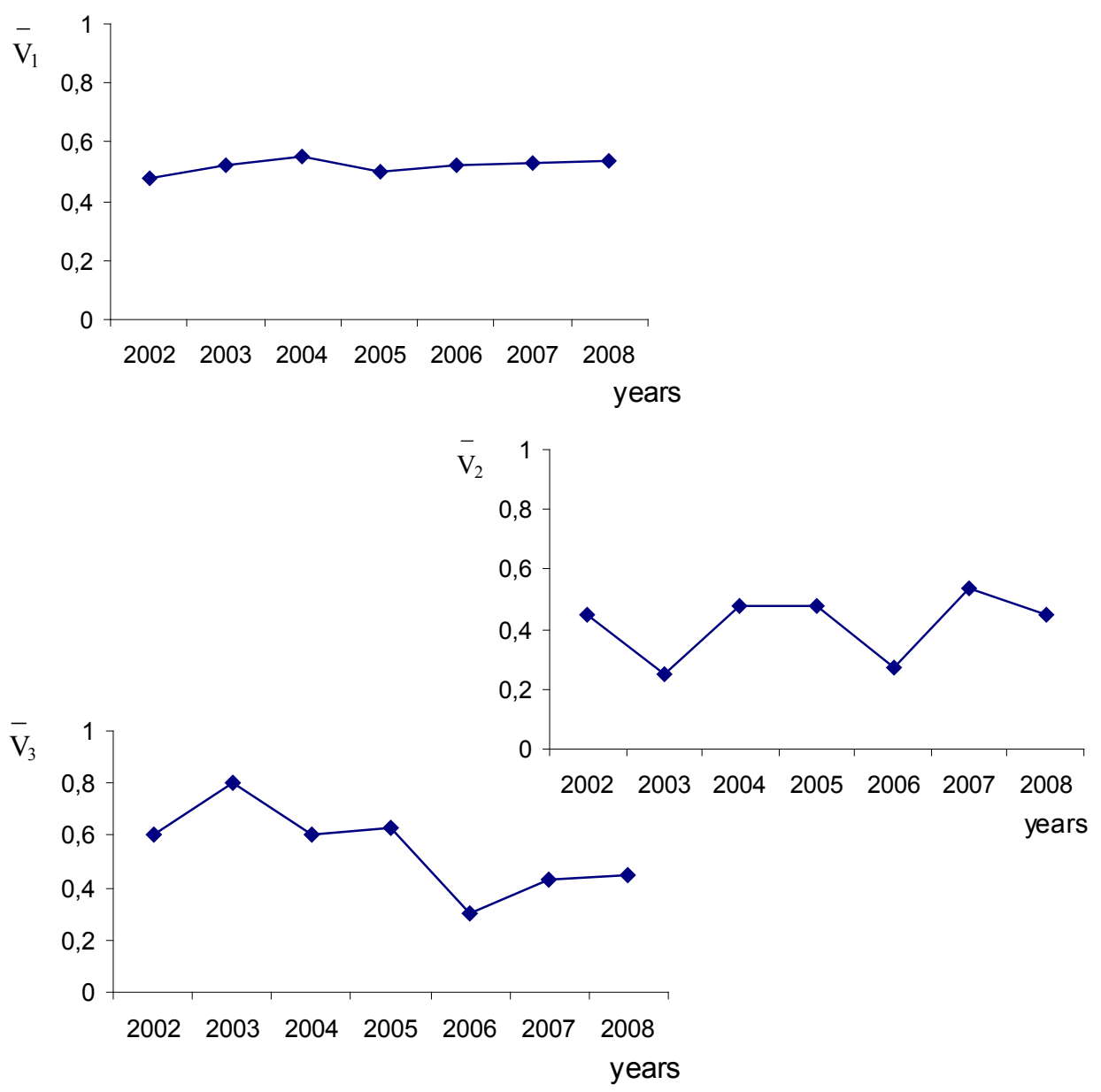

Fig. 3. Changes in the independent rates $V_{p}$ which characterise reliability of the 02 engine in the years $2002 \div 2008$

The latter means that the detectability of failures/damages to this engine is on the decrease within the maintenance system, and first and foremost, within the system 
of routine maintenance. This is to be attributed to more and more frequent occurrences (in the process of operating the engine) of failures/damages to the engine components difficult of access in the course of routine maintenance, with no warning given of their occurrences. First of all, this refers to failures like fatigue cracks usually detected in the course of periodical inspections.

\section{References}

1. Barziłowicz E. J. Mieziencew W. G., Sawienkow M. W. (1982). Nadiożnost awiacionnych sistem, Transport, Moskwa

2. Pigłas M. (1990), Metoda oceny właściwości urządzeń mechanicznych na podstawie informacji o ich uszkodzeniach $w$ systemie eksploatacji, Praca doktorska, WAT, Warszawa

3. Pluta W. (1972). Metoda wyboru zmiennych objaśniajacych w modelach symptomatycznych, Przegląd Statystyczny, t. 19, z. 2.

4. Pugaczew W. S. (1968). Wwiedjenije $w$ teoriju wierojatnostiej. Nauka, Moskwa

Scientific work was financed from the measures for research in years 2009-2011 as a development project No. O R00 008509.

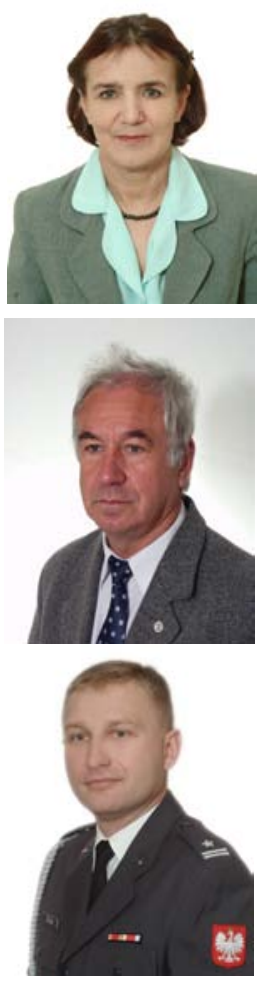

Antonina Krutkow MSc Eng. Air Force Institute of Technology, graduated from Warsaw University of Technology in 1998. M.Sc. in Transport specialized in Traffic Control. She is engaged in development and implementation of IT systems to support aircraft maintenance, safety and reliability management.

Mieczysław Piglas PhD Eng. Air Force Institute of Technology, graduated from Military University of Technology in 1978. M.Sc. in Mechanics specialized in Aircraft and Aircraft Engines. In 1991 achieved Ph.D. in Mechanical Engineering. For 20 years he has been engaged in development and implementation of IT systems to support aircraft maintenance, safety and reliability management.

Major Mariusz Zieja PhD Eng. Air Force Institute of Technology, graduated from Military University of Technology in 2000. M.Sc. in Mechatronics specialized in Aircraft Avionics. In 2008 achieved Ph.D. in Mechanical Engineering. He is engaged in development and implementation of IT systems to support aircraft maintenance, safety and reliability management. 